\title{
Entrepreneurial Activity Self-Production Conditions within Territorial Clusters
}

\author{
Daniil P. Frolov ${ }^{1}$, Victor O. Moseiko ${ }^{1} \&$ Sergei A. Korobov ${ }^{1}$ \\ ${ }^{1}$ Volgograd State University, Volgograd, The Russian Federation \\ Correspondence: Sergei A. Korobov, Department of Management, Volgograd State University, 400062, \\ Volgograd, Universitetsky Prospect, 100, The Russian Federation. Tel: 7-844-240-5519. E-mail: \\ korobovfamily@mail.ru
}

Received: February 23, 2015 Accepted: March 16, 2015 Online Published: June 13, 2015

doi:10.5539/ass.v11n20p9 URL: http://dx.doi.org/10.5539/ass.v11n20p9

\begin{abstract}
The role of regional entrepreneurship is becoming the key point when forming Russian economy effective competitiveness and especially in terms of current world economic challenges, which determines Russian economy turbulence. The current research focuses on self-production conditions of these territorial systems clusters. A cluster's formation based on its members' self-production is thoroughly investigated in the research. The authors analyze clusters, their functions, and tasks definitions of economic analysis. The features of various territorial-production systems of the Russian Federation are considered in the article. Clusters competitive nature is clarified on the grounds of the analysis by using various resources and combinations of factors. An algorithm for forming business self-production conditions within a cluster is defined in the research. The research provides the analysis results of cluster business self-production formation conditions. The key integrating resource, which plays the role of a moving force for development of other resources that are necessary for forming business self-production conditions within a cluster, is elaborated in the article. On the basis of economic territorial systems with self-production features functioning analysis, the authors suggest a new economic approach to business system development by applying new cluster organization forms.
\end{abstract}

Keywords: clusters, economic development, entrepreneurship, regional economy, resource management

\section{Introduction}

Territorial clusters, being effective forms of territorial organization of the economic entities economic interaction, proved to be efficient since the beginning of the $20^{\text {th }}$ century. Through the territorial development it became evident that territorial economic system's cluster functioning form provided successful development to regions by creating business self-production conditions within these clusters.

\section{Latest Research and Publication Analysis}

It is apparent that cluster economic organization should be regarded as the modern form of economic organization or economic entities' interaction in various primarily economic interaction cooperative forms. Cluster economic organization is characteristic of market economic environment and thus is a market form of cooperative interaction development, as latter implies the business entities' amalgamation around a certain functional niche, product, or service and the presence of interrelations and working relations for increasing these businesses' competitiveness.

We consider that cluster economic organization's main systemic quality is business self-production within a cluster, which distinguishes it from the cooperative interaction form. Taking this into consideration, each business entity's interaction with other territorial cluster entities depends on the entity itself and its view on such interaction economic expedience.

It is worth mentioning that if the economic cooperation was determined primarily by the inter-business directive organization forms in the framework of planned economy, then in the framework of market economy we should look for new task solutions. Cluster economic organization functions on a market, where market behavior is characteristic of all cluster members, which in general excludes any kind of concrete cluster directive management. 
The presence of directive influence forms of some authority body in concrete cluster's formation and functioning creates prerequisites for such economic systems' systemic privacy. Sometimes such prerequisites may become a stagnating condition for directly formed and managed cluster systems.

\section{Objectives and Methods}

Current article covers the self-production conditions of the territorial economic systems, called cluster. In this article we will formulate the answer to the question of condition, which provide a cluster's formation on the basis of its members' self-production.

There is no single theory of clusters (Özcan, 2004). It is worth emphasizing that the cluster conception has a big number of explanations, ways of application and meanings in connecting various spatial processes under one universal notion. For example, Porter M. defines the industrial cluster as several sectors, connected through the seller-buyer relation or through common technologies, common purchase or distribution channels, or common labor associations (Porter, 1990). According to Schmitz H., a cluster is a group of enterprises, belonging to one sector and functioning closely to each other (Schmitz, 1992). Rosenfeld S.A. considers that a cluster is a concentration of enterprises, which can produce synergic effect, due to their geographical proximity, even though their preoccupation may not be really evident (Rosenfeld, 1997). Crouch C. and Farrell H. believe that a cluster's wider understanding implies the tendency for the enterprises to function closely to each other (Crouch \& Farrell, 2001). According to Van den Berg, Braun, and van Winden, the popular term "cluster" is closely connected with the range of local or regional networks. Most cluster definitions say that a cluster is a network of localized oriented organizations which production processes are closely connected through goods, services, or expertise exchange (Van den Berg, Braun, \& van Winden, 2001). Andersson T., Schwaag-Serger S., Sorvik J., and Wise Hansson E. define clustering as a process of the enterprises and other entities joint disposition within a concentrated geographical area, cooperation of a certain functional niche and within work alliances for enhancing these entities collective competitiveness (Andersson, Schwaag-Serger, Sorvik, \& Wise Hansson, 2004). Other researchers (Swann \& Prevezer, 1996; Bergman \& Feser, 1999; Visser \& Boschma, 2002; Vázquez-Barquero, 2006; Potter \& Miranda, 2009; Villa \& Antonelli, 2009; Monteiro, Noronha, \& Neto, 2011; Wise \& Johansson, 2012) adhere to this view.

Firstly, we should say that cluster conception is elastic, which obviously is an advantage if considering the conception in a broad sense. High variability in determining clusters should not be a challenge to defining prerequisites and conditions which facilitate the clusters' formation and self-production in this or that area.

Thus, most clusters are viewed as an association of functioning economic entities, united by certain technological and production relations that help these entities produce goods. Services can also be a kind of product, uniting entities.

We consider this view on cluster to be logic and well-grounded, until we try to define conditions and prerequisites for a cluster formation.

The same features are regarded as the cause and the consequence of a cluster formation, so we suggest regarding these features as the consequence, i.e. the result of a cluster formation.

It is a typical mistake to consider the presence or the absence of an association of entities, united by definite relations, i.e. interacting with each other, as the main condition or cause for clusters' existence. This assumption usually leads to wrong decisions, aimed at administrative or directive cluster formation. Nowadays in Russia we can observe examples of administrative economic cluster organization, implemented by means of decisions, targeted at primarily organization-directive transformations in a region, district, or state. Such economic entities association is nothing but an attempt to create a complicated formation by means of directive approach, which seems to be absurd in market conditions. Of course, it doesn't necessarily mean that the formations, created in this way, should be unsuccessful, because we still remember the examples of production complexes' or territorial-production complexes' centrally planned economy. Such formations effectiveness can be provided even in terms of market economy. But in the narrow sense, a cluster is territorial production complex which cannot be formed and operated directly. A cluster is an association of entities, functioning by themselves in terms of competition, i.e. it is a self-governing socio-economic system, formed by the entities' self-production. That is why directive regional government decisions on forming territorial clusters by organizing or creating appropriate research, production, and education units, may not always be a right thing to do.

If we answer the question "What is an essential condition for forming a territorial cluster or for forming business self-production within this cluster?", we will be able solve the above mentioned problem. The answer to this 
question will allow conceptualizing what clusters are, what their features are, and making conclusions, necessary for building economic policy.

To find the answer to the question, we shall consider various Russian territorial-production systems, having characteristic cluster features and function peculiarities (See Table 1). The study is supposed to be implemented by quality analysis of the conditions and factors which influence the territorial-production systems formation and functioning. The analysis aim is to define the way these conditions and factors affect production systems and to define the common features of such influence for different territories.

The main methodological toolset, used for the analysis, comprises the basic key notions of the competitive theory, namely competitiveness and socio-economic systems (mainly cluster economic systems) competitive advantages.

Table 1. Territorial economic systems (cluster economic systems) examples with business activity self-production features within a cluster

\begin{tabular}{|c|c|c|c|c|}
\hline № & Economic system & Essence & $\begin{array}{l}\text { The main integrating } \\
\text { resource-condition }\end{array}$ & $\begin{array}{c}\text { Integrating resource } \\
\text { interpretation }\end{array}$ \\
\hline 1 & 2 & 3 & 4 & 5 \\
\hline 1 & $\begin{array}{l}\text { “Avtogrady" (automobile } \\
\text { unions) in Tolyatti, } \\
\text { Naberezhnye Chelny, Nizhniy } \\
\text { Novgorod, and Kaliningrad. }\end{array}$ & $\begin{array}{l}\text { A system, promoting cars } \\
\text { and tying goods. }\end{array}$ & $\begin{array}{l}\text { Producing cars by large } \\
\text { car-makers. }\end{array}$ & $\begin{array}{l}\text { Produced or } \\
\text { artificially created } \\
\text { resources. }\end{array}$ \\
\hline 2 & $\begin{array}{l}\text { Wood processing companies } \\
\text { and complexes in Karelia, } \\
\text { Siberia, Vologda Oblast, etc. }\end{array}$ & $\begin{array}{l}\text { Harvesting, processing, } \\
\text { and selling the wood. }\end{array}$ & Wood stock. & Natural resources. \\
\hline 3 & Krasnodar Krai Agriculture. & $\begin{array}{c}\text { Producing, processing, } \\
\text { and selling agricultural } \\
\text { production. }\end{array}$ & $\begin{array}{l}\text { Natural-landscape and } \\
\text { climate conditions. }\end{array}$ & Natural resources. \\
\hline 4 & $\begin{array}{l}\text { Sanatorium-resort and tourist } \\
\text { industry of the Russian } \\
\text { Federation Black Sea coast. }\end{array}$ & $\begin{array}{l}\text { A system for promoting } \\
\text { tourism products. }\end{array}$ & $\begin{array}{l}\text { Natural and climate } \\
\text { conditions. }\end{array}$ & Natural resources. \\
\hline 5 & $\begin{array}{l}\text { Fishing and fish-processing } \\
\text { enterprises in Caspian, } \\
\text { Primorski, and Baltic areas. }\end{array}$ & $\begin{array}{l}\text { Fishing, processing and } \\
\text { selling fish and fish } \\
\text { products, necessary } \\
\text { infrastructure. }\end{array}$ & Fish and seafood stock. & Natural resources. \\
\hline 6 & $\begin{array}{l}\text { Modern regional business } \\
\text { incubators. }\end{array}$ & $\begin{array}{l}\text { A system promoting the } \\
\text { innovations } \\
\text { commercialization. }\end{array}$ & $\begin{array}{c}\text { Research-and-production } \\
\text { infrastructure. }\end{array}$ & $\begin{array}{l}\text { Produced or } \\
\text { artificially created } \\
\text { resources. }\end{array}$ \\
\hline 7 & $\begin{array}{l}\text { Metallurgical and } \\
\text { metal-working sector of } \\
\text { Southern Urals. }\end{array}$ & $\begin{array}{l}\text { Producing, processing, } \\
\text { and selling metallurgical } \\
\text { production. }\end{array}$ & $\begin{array}{l}\text { Producing metallurgical } \\
\text { production by large } \\
\text { enterprises. }\end{array}$ & $\begin{array}{l}\text { Produced or } \\
\text { artificially created } \\
\text { resources. }\end{array}$ \\
\hline 8 & $\begin{array}{c}\text { Modern shopping, } \\
\text { shopping-expo and } \\
\text { shopping-entertainment malls. } \\
\text { Vegetable-producing }\end{array}$ & $\begin{array}{l}\text { A system of retail trade, } \\
\text { leisure, and entertainment. }\end{array}$ & $\begin{array}{l}\text { Trade and leisure } \\
\text { infrastructure. }\end{array}$ & $\begin{array}{l}\text { Produced or } \\
\text { artificially created } \\
\text { resources. }\end{array}$ \\
\hline 9 & $\begin{array}{l}\text { enterprises in } \\
\text { Volgo-Akhtubinskaya } \\
\text { floodplain in Volgograd Oblast } \\
\text { (in the Soviet time). }\end{array}$ & $\begin{array}{l}\text { Producing and selling } \\
\text { vegetables (fresh and } \\
\text { tinned). }\end{array}$ & $\begin{array}{l}\text { A system of floodplain } \\
\text { irrigation. }\end{array}$ & $\begin{array}{l}\text { Produced or } \\
\text { artificially created } \\
\text { resources. }\end{array}$ \\
\hline 10 & $\begin{array}{c}\text { Producing fine jewelry and } \\
\text { souvenirs in } \\
\text { Krasnoe-na-Volge, Kostroma } \\
\text { Oblast and Kubachi, } \\
\text { Dakhaevskiy District, the } \\
\text { Republic of Dagestan. }\end{array}$ & $\begin{array}{l}\text { Producing and selling fine } \\
\text { jewelry and souvenirs. }\end{array}$ & $\begin{array}{c}\text { Old traditions and } \\
\text { knowledge, passed across } \\
\text { generations, } \\
\text { Specialized professional } \\
\text { personnel training. }\end{array}$ & $\begin{array}{l}\text { Produced or } \\
\text { artificially created } \\
\text { resources. }\end{array}$ \\
\hline
\end{tabular}


The product's competitive advantages by nature.

A product's feature (either a material product or service) is created in the production process and is determined by the use of appropriate resources and factors.

Thus, the main (basic) production factors are: equipment and technological processes, personnel, natural and other materials, organization technologies, information and institutional support. All together these factors represent possible specific product's manufacture resources and factors.

Each production factor (and, consequently, the corresponding object, process, and condition of environment) buries certain features, qualities, and characteristics, which determine the way this factor is applied in the production process. Any economic or business entity within a cluster develops nature conditions and things which gradually become production resources and factors. The resources' and factors' competitive advantages later transform into a product's competitive advantages, which provides competitiveness for the cluster members and for the cluster as a whole. Thus, an economic entity's joining a cluster determines its business self-production within the cluster system. This is determined by an entity's tendency to get certain competitive advantages within a definite cluster. That is why finding cluster economic systems formation conditions or their business self-production conditions should be done by providing competitiveness or competitive advantages by developing new appropriate resources.

\section{Results}

Let us return back to territorial economic systems with business self-production features within clusters (See Table 1).

We should first of all distinguish the business self-production formation and this process's result (See Figure 1). Various approaches, methods, and tools which all together make up the mechanism for achieving the result, are used for implementing the process.

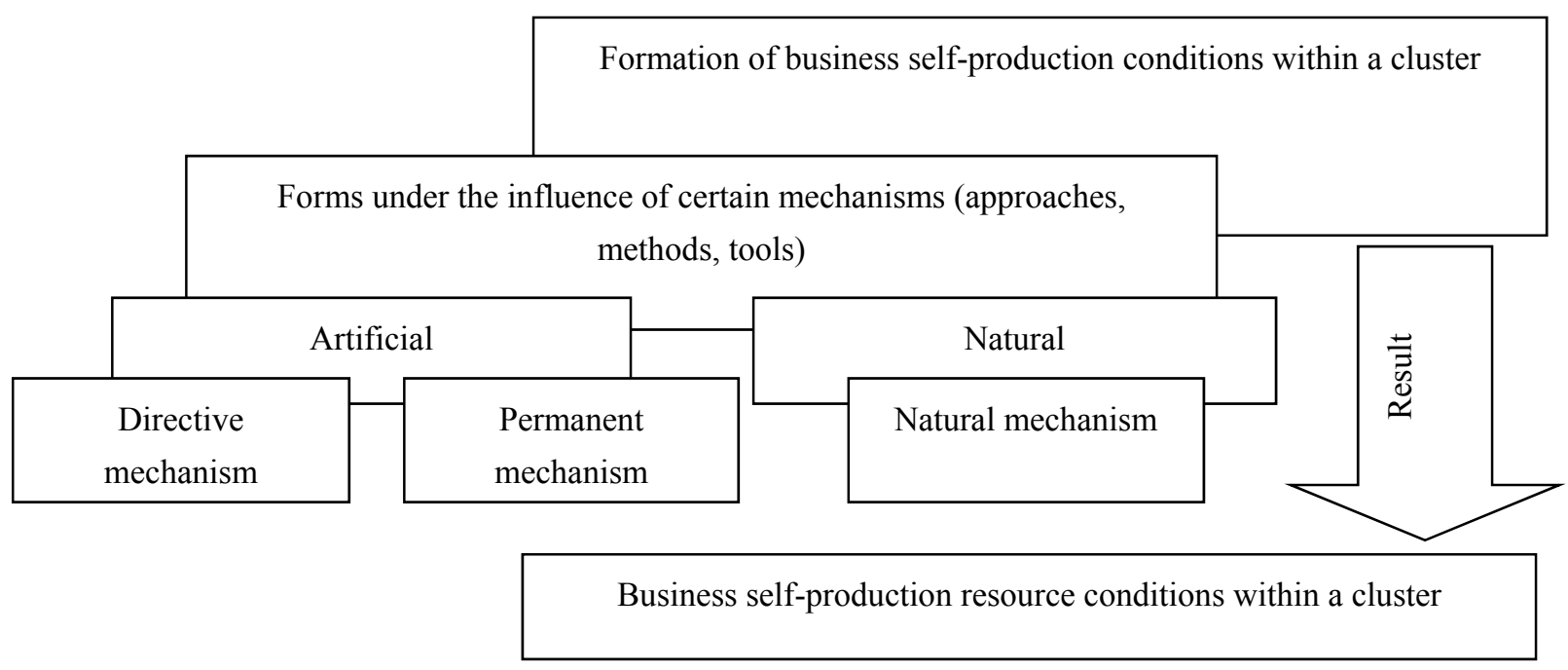

Figure 1. The formation process and result of the business self-production conditions within a cluster

As to the nature of business self-production conditions formation and its mechanism, we suppose that it's better to make a distinction between the natural and artificial (manmade) nature. In the first case, the formation mechanism may be directive or permanent and in the second - only natural.

Primarily, business self-production resources should be the result of the business self-production conditions formation.

The results of analyzing business self-production formation process and formation mechanism within an economic cluster system are shown in the table below (See Table 2). 
Table 2. The nature of the business self-production formation mechanism and process within clusters

\begin{tabular}{|c|c|c|}
\hline № & Economic system & $\begin{array}{l}\text { The resource conditions formation } \\
\text { mechanisms by nature }\end{array}$ \\
\hline 1 & 2 & 3 \\
\hline & "Avtogrady" (automobile unions) in Tolyatti, & \\
\hline 1 & $\begin{array}{l}\text { Naberezhnye Chelny, Nizhniy Novgorod, and } \\
\text { Kaliningrad. }\end{array}$ & Directive mechanism, artificial by nature. \\
\hline 2 & $\begin{array}{l}\text { Wood processing companies and complexes in Karelia, } \\
\text { Siberia, Vologda Oblast, etc. }\end{array}$ & Natural mechanism. \\
\hline 3 & Krasnodar Krai Agriculture. & Natural mechanism. \\
\hline 4 & $\begin{array}{l}\text { Sanatorium-resort and tourist industry of the Russian } \\
\text { Federation Black Sea coast. }\end{array}$ & Natural mechanism. \\
\hline 5 & $\begin{array}{l}\text { Fishing and fish-processing enterprises in Caspian, } \\
\text { Primorski, and Baltic areas. }\end{array}$ & Natural mechanism. \\
\hline 6 & Modern regional business incubators. & Directive mechanism, artificial by nature. \\
\hline 7 & $\begin{array}{l}\text { Metallurgical and metal-working sector of Southern } \\
\text { Urals. }\end{array}$ & Directive mechanism, artificial by nature. \\
\hline 8 & $\begin{array}{l}\text { Modern shopping, shopping-expo and } \\
\text { shopping-entertainment malls. }\end{array}$ & Directive mechanism, artificial by nature. \\
\hline & enterprises & \\
\hline 9 & $\begin{array}{l}\text { Volgo-Akhtubinskaya floodplain in Volgograd Oblast } \\
\text { (in the Soviet time). }\end{array}$ & Directive mechanism, artificial by nature. \\
\hline 10 & $\begin{array}{l}\text { Producing fine jewelry and souvenirs in } \\
\text { Krasnoe-na-Volge, Kostroma Oblast and Kubachi, } \\
\text { Dakhaevskiy District, the Republic of Dagestan. }\end{array}$ & Permanent mechanism, artificial by nature \\
\hline
\end{tabular}

It is worth noting that, taking into account all factorial conditions which affect the systems' formation and functioning, it is necessary to identify the main integrating resource-condition in each example (See Table 1, column 4). This integrating condition is the key factor of the clusters' development and their business self-production. Still, it is evident that various resources, used for the territorial clusters' organizing and functioning, have a different impact on their business self-production. We should distinguish the resources which bear significant importance for self-production conditions formation. Let's consider the following hypothetic example.

The fish-processing sector in Primorskiy Krai, the Russian Federation Far East, is developing in the form of regional sectorial clusters. Is it possible for such sector to function in the Republic of Kalmykia? Obviously, not. This would be economically absurd and, therefore, impossible. The same would be if we try developing logging business in Kalmykia.

It's worth mentioning that even despite developing other essential resource conditions, such as financing, human (personnel training), and organizational (directive decisions), the establishment of a fish- or wood-processing sector in Kalmykia would still be absurd.

That is why the fish stock in Primorskiy Krai and wood stock in Karelia or Siberia are the unique resource conditions for the clusters, functioning in those areas. This is why business self-production takes place within appropriate territorial clusters, where the key resource conditions are available.

Such integrating key resource, as the production factor, works as a moving force for developing other resources, essential for creating self-production conditions (finance, personnel training, technological capability, directive decisions), but not vice versa.

As you might have already noticed, the main integrating condition can be natural and artificial by nature. In the first case, enterprises which produce goods and provide the integrating condition take the role of a cluster's nucleus on the basis of each territorial economic system.

In the second case, when natural resource is the main integrating condition, there may not be any evident cluster nucleus. Thus, there is no evident nucleus or enterprise which could integrate other cluster members in logging, fish-processing, or tourism sectors. 
We also note that such approach to interpreting a process's nature or a mechanism's business self-production conditions within clusters might be rather relative.

Therefore, if we take natural integrating resources, we should not reject the importance of the impact of business self-production conditions within clusters and directive elements' significance.

\section{Conclusion}

The analysis of the main integrating condition's substance for each territorial economic system allows highlighting the following features of this condition (resource):

1. This resource should be equally available to all territorial economic system members (sometimes primarily including) small and medium businesses. In case there are (administrative-directive) barriers which impede this resource's development, the natural self-production condition of territorial economic system members will be impossible. In case some restrictions (ecological, humanitarian) are inevitable, they should affect all cluster members equally.

2. This resource provides a cluster's general production considerable competitive advantages. This particular resource development makes the production process, in the framework of a certain cluster, more competitive by this resource's development low costs, if comparing with the production costs in other territorial clusters. In this sense, resource's territorial-sectorial property possesses phenomenological quality.

3. The lack or full absence of this resource may be compensated by other territorial-sectorial sources. Each of the above mentioned clusters (See Table 1) couldn't have developed if there was a lack or absence of this resource; that would have led to stagnation or collapse of the cluster economic system. Replenishing this lack leads to greater costs, in comparison with other resources replenishment. It is worth saying that the lack of this resource cannot be compensated by other resources.

4. The more intensively this integrating resource is developed, the more the corresponding territorial-sectorial economic system is developed, if comparing with other resources active development. Replacing intensive integrating resource's development with other resources' active development is economically unreasonable. Thus, for instance, the development of nature-landscape resources would be of greater importance for the logging or agricultural.

5. The intensive integrating resource's development contributes to the more active development of other resources. Still, this doesn't work vice versa. Therefore, the integrating resource is multiplicative. So, it is evident, that more intensive human resource development won't influence other resources' development as much as the appropriate integrating resources' development does.

6. If the decision to create territorial clusters has been taken directly, then its substance should be aimed at developing and providing corresponding integrative resources. Only this way creating a territorial cluster may be successful.

These conclusions on territorial economic systems functioning with cluster and business self-production features do not contradict the main known cluster theory theses.

\section{Acknowledgments}

This work was supported by the Russian Foundation for Humanities (project 15-12-34012).

\section{References}

Andersson, T., Schwaag-Serger, S., Sorvik, J., \& Wise Hansson, E. (2004). The Cluster Policies Whitebook, IKED (p. 250).

Bergman, E. M., \& Feser, E. J. (1999). Industrial and Regional Clusters: Concepts and Comparative Applications. Retrieved February 15, 2015, from http://www.rri.wvu.edu/WebBook/Bergman-Feser/ contents.htm

Crouch, C., \& Farrell, H. (2001). Great Britain: Falling through the holes in the Network Concept. In C. Crouch, P. Le Galés, C. Trogilia, \& H. Voelzkow (Eds.), Local Production System in Europe: Rise or Demise? (pp. 161-211). Oxford: Oxford University Press.

Monteiro, P. V., Noronha, T., \& Neto, P. (2011). The Importance of Clusters for Sustainable Innovation Processes: The Context of Small and Medium Sized Regions. Retrieved February 17, 2015, from

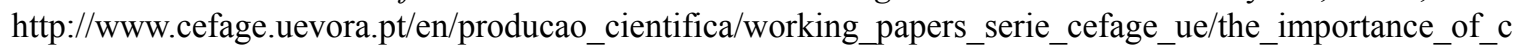
lusters_for_sustainable_innovation_processes_the_context_of_small_and_medium_sized_regions 
Özcan, S. (2004). Institutions, Institutional Innovation and Institutional Change in Clusters. Retrieved February 17, 2015, from http://www.druid.dk/uploads/tx_picturedb/dw2004-902.pdf

Porter, M. E. (1990). The Competitive Advantage of Nations (p. 896). London, Macmillan.

Potter, J., \& Miranda, G. (2009). Clusters, Innovation and Entrepreneurship (p. 233). OECD.

Rosenfeld, S. A. (1997). Bringing Business Clusters into the Mainstream of Economic Development. European Planning Studies, 5(1), 3-23. http://dx.doi.org/10.1080/09654319708720381

Schmitz, H. (1992). On the Clustering of Small Firms. IDS Bulletin, 23(3), 64-69. http://dx.doi.org/10.1111/j.1759-5436.1992.mp23003012.x

Swann, G., \& Prevezer, M. (1996). A Comparison of the Dynamics of Industrial Clustering in Computing and Biotechnology. Research Policy, 25(7), 1139-1157. http://dx.doi.org/10.1016/S0048-7333(96)00897-9

Van den Berg, L., Braun, E., \& van Winden, W. (2001). Growth Clusters in European Cities: An Integral Approach. Urban Studies, 38(1), 185-205. http://dx.doi.org/10.1080/00420980124001

Vázquez-Barquero, A. (2006). Emergence and transformation of clusters and milieus. Retrieved February 17, 2015, from http://www-sre.wu-wien.ac.at/ersa/ersaconfs/ersa06/papers/648.pdf

Villa, A., \& Antonelli, D. (2009). A Road Map to the Development of European SME Networks. Towards Collaborative Innovation (2nd ed., p. 189). London: Springer. http://dx.doi.org/10.1007/978-1-84800-342-2

Visser, E.-J., \& Boschma, R. (2002). Clusters and networks as learning devices for individual firms. Retrieved February 15, 2015, from http://ecsocman.hse.ru/data/463/656/1219/clust.pdf

Wise, E., \& Johansson, C. (2012). Where the cluster winds are blowing in Europe. Better cluster policies and tools for implementation. Retrieved February 16, 2015, from http://www.vinnova.se/upload/EPiStorePDF/ Tactics_ClusterWinds.pdf

\section{Copyrights}

Copyright for this article is retained by the author(s), with first publication rights granted to the journal.

This is an open-access article distributed under the terms and conditions of the Creative Commons Attribution license (http://creativecommons.org/licenses/by/3.0/). 